DE

M E D I C I N A

T R O P I C A L

$\mathrm{DE}$

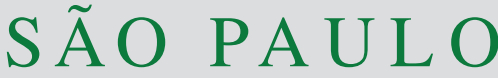

JOURNAL OF THE SÃO PAULO INSTITUTE OF TROPICAL MEDICINE

1Universidad Cooperativa de Colombia, Centro de Investigación en Salud para el Trópico, Santa Marta, Colombia

2Universidad de La Salle, Departamento de Ciencias Básicas, Programa de Biología, Bogotá, Colombia

${ }^{3}$ Instituto Nacional de Salud, Dirección de Redes en Salud Pública, Grupo de Virología, Bogotá, Colombia

${ }^{4}$ Secretaría de Salud Distrital, Programa de Enfermedades Transmitidas por Vectores, Santa Marta, Colombia

${ }^{5}$ Universidad del Magdalena, Grupo de Investigación Evolución, Sistemática y Ecología Molecular, Santa Marta, Colombia

${ }^{6}$ Instituto Nacional de Salud, Subdirección de Innovación en Salud Publica, Bogotá,

Colombia

Correspondence to: Gabriel Parra-Henao Universidad Cooperativa de Colombia, Centro de Investigación en Salud para el Trópico, Troncal del Caribe Sector Mamatoco, Edificio de la Salud Piso 3, Santa Marta, Colombia

Tel: +573116471341

E-mail: gabriel.parrah@ucc.edu.co

Received: 3 October 2020

Accepted: 19 January 2021

\section{Molecular characterization of mosquitoes (Diptera: Culicidae) from the Colombian rainforest}

\author{
Andrew S. Muñoz-Gamba ${ }^{1,2}$, Katherine Laiton-Donato ${ }^{(1)}$, Erick \\ Perdomo-Balaguera ${ }^{4}$, Lyda R. Castro ${ }^{5}$, José A. Usme-Ciro ${ }^{10}$, Gabriel \\ Parra-Henao (1) 1,6
}

\section{ABSTRACT}

A few studies have carried out the taxonomic and molecular characterization of sylvatic mosquito species in Latin America, where some species have been incriminated as vectors for arboviruses and parasites transmission. The present study reports the molecular characterization of mosquito species in the Sierra Nevada de Santa Marta, a natural ecosystem in the Northern coast of Colombia. Manual capture methods were used to collect mosquitoes, and the specimens were identified via classical taxonomy. The COI marker was used for species confirmation, and phylogenetic analysis was performed using the neighborjoining method, with the Kimura-2-Parameters model. Aedes serratus, Psorophora ferox, Johnbelkinia ulopus, Sabethes chloropterus, Sabethes cyaneus, Wyeomyia aporonoma, Wyeomyia pseudopecten, Wyeomyia ulocoma and Wyeomyia luteoventralis were identified. We assessed the genetic variability of mosquitoes in this area and phylogenetic reconstructions allowed the identification at the species level. Classical and molecular taxonomy demonstrated to be useful and complementary when morphological characteristics are not well preserved, or the taxonomic group is not represented in public molecular databases.

KEYWORDS: Culicidae. DNA barcoding. COI, morphology. Taxonomy.

\section{INTRODUCTION}

The family Culicidae comprises 3,600 species, which are classified in the subfamilies Anophelinae and Culicinae. Anophelinae comprises the genera Anopheles, Bironella, and Chagasia, while the subfamily Culicinae includes the tribes Aedeomyiini, Aedini, Culicini, Culisetini, Ficalbiini, Hoggesiini, Mansoniini, Orthopodomyiini, Sabethini, Toxorhynchitini, and Uranotaeniini, comprising around 110 genera ${ }^{1}$. Different viruses have been associated with diseases, such as Dengue virus (DENV) that produces over 40,000 deaths every year ${ }^{2}$ among others. The relationship between different taxonomic groups of viruses and mosquitoes is ancestral, with a recent description of a huge diversity of insect-specific viruses that may constitute the source for the future, leading to emerging viral diseases through species jumping from enzootic to epizootic and epidemic cycles ${ }^{3}$.

Classical taxonomy has allowed us to obtain information about mosquito species through the definition of morphological characteristics used in dichotomic keys, leading to a clustering that may not always be monophyletic or similar in their distribution in ecosystems ${ }^{4}$. However, as the knowledge of biological species has become more detailed, the International Commission on Zoological Nomenclature (ICZN) explains what names in species are correct in a family, genus and at the 
species level and uses a classification of specimens such as type series, name-bearing types and other specimens ${ }^{5}$. The presence of cryptic species cannot be separated by morphological characteristics ${ }^{6}$ which also contribute to the problem. Molecular systematics is a complementary strategy to determine the evolutionary relationship between species that have been difficult to determine via morphological characteristics, development states, and sexual dimorphism ${ }^{7}$. DNA barcoding was established in 1993 as a strategy to unify the use of molecular markers for species identification and taxonomic allocation through phylogenetic inference based on genetic variability ${ }^{8}$. The cytochrome oxidase c subunit I (COI) gene has been widely used for molecular identification and, together with classical taxonomy, is a powerful tool for mosquito species demarcation ${ }^{9}$.

In Colombia, some studies have used DNA barcoding through COI, internal transcribed spacer 2 (ITS2), and $16 \mathrm{~S}$ subunit genes, which have allowed to characterize the phylogenetic relationship of several species belonging to the genera Aedes, Anopheles, and Culex ${ }^{10-12}$. Hematophagous mosquitoes involved in arbovirus transmission in the Sierra Nevada de Santa Marta (SNSM) have not been extensively studied $^{13}$, and there are no reports that include molecular taxonomy. In the present study, we investigated the diversity of rainforest mosquito species in a unique ecosystem in Colombia using DNA barcoding and classical taxonomy. The accurate identification of mosquito species is essential to determine the real and potential risk of arboviruses or parasites transmission and to implement vector surveillance and control programs.

\section{MATERIALS AND METHODS}

\section{Study area}

Mosquito specimens were collected following the technical and ethical approval (CEMIN-6-2017 from the Instituto Nacional de Salud, Bogota D.C., Colombia), in the SNSM foothills near Guachaca village, corresponding to the sylvatic area of Quebrada Valencia - La Piedra $\left(11^{\circ} 14^{\prime} 22.6^{\prime \prime} \mathrm{N}, 73^{\circ} 47^{\prime} 58.3^{\prime \prime} \mathrm{W}\right)$ at an altitude of 80 meters above sea level (Figure 1). The region is characterized by bimodal type rains due to the variation in precipitation, which decreases in the Southeastern slope and increases in the Northern slope, leading to the formation of a hydrographic system. Temperatures during the year range from $28{ }^{\circ} \mathrm{C}$ to less than $0{ }^{\circ} \mathrm{C}$ in the highest altitude areas, and there is a distribution of eight biomes along the SNSM depending on altitude, climate, geographical and physicochemical conditions ${ }^{14,15}$.

\section{Mosquito collections and identification}

Mosquitoes were collected during two field expeditions

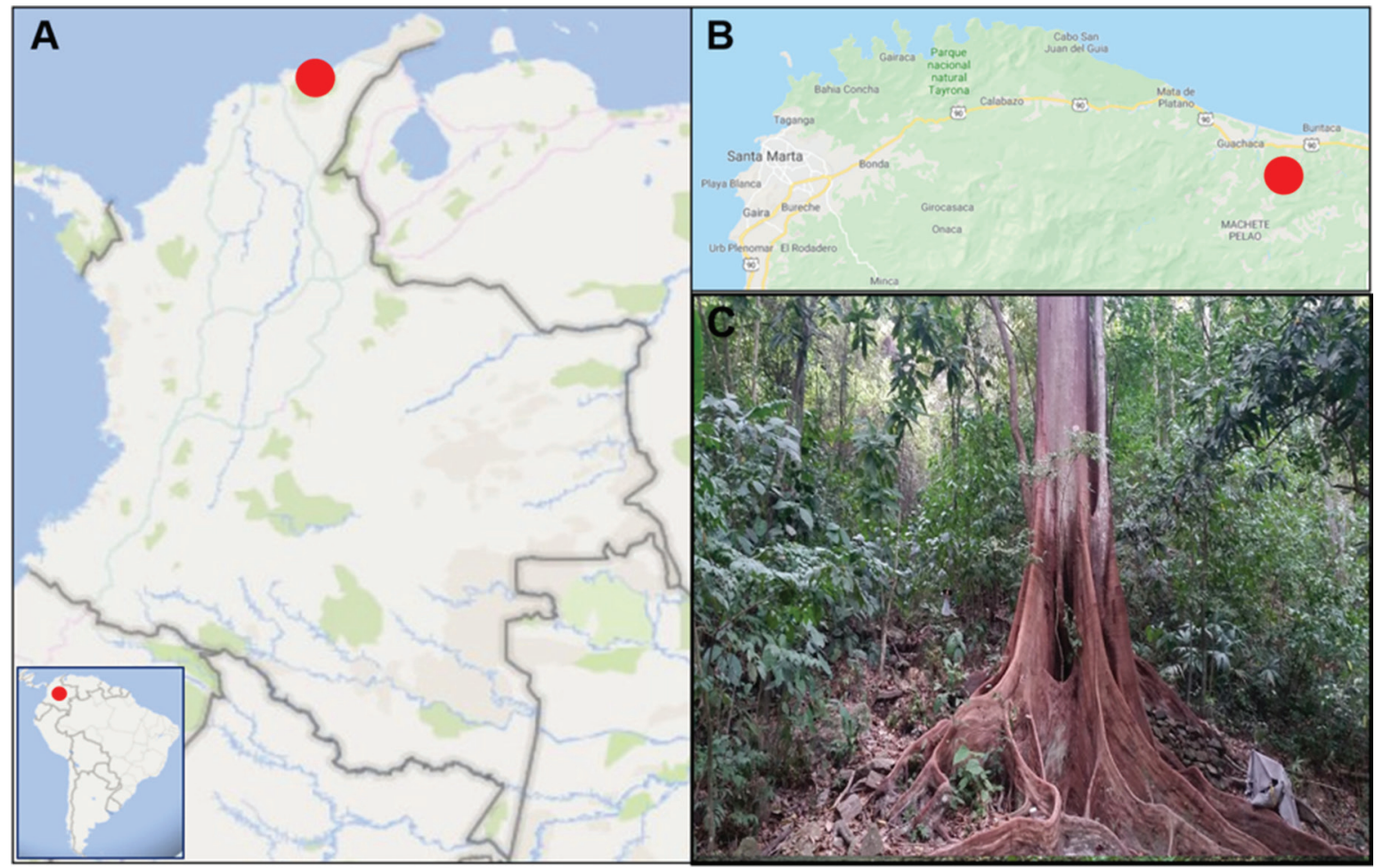

Figure 1 - Rainforest in Sierra Nevada de Santa Marta, Colombia: (A) Location of the SNSM rainforest area, (B) Guachaca locality, and (C) Quebrada Valencia-La Piedra forest. 
during two days per month, between August to December 2018, the season with the highest rainfall incidence. Linear transects of $2 \mathrm{~km}$ were delimited inside the sampling area. The collection methods used were manual capture by entomological nets and aspirators, between 07:00-12:00 a.m. hours and 02:00-04:00 p.m. hours. Collected mosquitoes were transported in containers to the entomology laboratory at the Tropic Health Research Center (CIST) and sacrificed with ethyl ether. Subsequently, mosquitoes were identified using dichotomic keys ${ }^{16-18}$. The code structure CIST\#\#\#\# was used to register and deposit specimens into the entomological collection. Finally, the specimens were stored in vials with 1 $\mathrm{mL}$ of $96 \%$ ethanol for subsequent molecular characterization of female mosquitoes.

\section{Molecular analysis}

\section{DNA extraction}

Mosquito legs were removed using sterile tweezers. Homogenization was performed with nuclease-free zirconium beads, and DNA extraction was carried out using the DNeasy Blood \& Tissue kit (QIAGEN Inc., Hilden, Germany). following the manufacturer's instructions.

\section{COI gene amplification}

The standard 658 base pairs (bp) barcode region of the mitochondrial COI gene was amplified using the primers $\mathrm{LCO} 1490$ and $\mathrm{HCO} 2198^{19}$. The reaction mixture included $5 \mu \mathrm{L}$ of extracted DNA, $0.4 \mu \mathrm{M}$ of each primer, 1.25 U GoTaq DNA Polymerase (Promega), $0.2 \mathrm{mM}$ of each dNTP, $1 \mathrm{X}$ buffer with $1.5 \mathrm{mM} \mathrm{MgCl}_{2}$, and nuclease free water for a final volume of $25 \mu \mathrm{L}$. The thermal profile consisted of an initial denaturation step at $94{ }^{\circ} \mathrm{C}$ for $10 \mathrm{~min}$; followed by 35 cycles at $95{ }^{\circ} \mathrm{C}$ for $60 \mathrm{~s}$ for denaturation, $50{ }^{\circ} \mathrm{C}$ of $60 \mathrm{~s}$ for annealing, and $72{ }^{\circ} \mathrm{C}$ of $60 \mathrm{~s}$ for extension; and then a final extension at $72{ }^{\circ} \mathrm{C}$ of $5 \mathrm{~min}$. A $5-\mu \mathrm{L}$ aliquot of each PCR product was used to visualize the expected amplicon through an agarose gel electrophoresis. The quantification of amplicons was performed by using a NanoDrop ${ }^{\mathrm{TM}}$ 2000 Spectrophotometer (Thermo Fisher Scientific Inc., Waltham, MA, USA) with a range between 26 to $431.5 \mathrm{ng} / \mu \mathrm{L}$, which were subsequently purified by using the ExoSAP-IT ${ }^{\mathrm{TM}}$ PCR Product Cleanup Reagent enzyme (Thermo Fisher Scientific Inc. Waltham, MA, USA).

\section{DNA Sequencing}

The purified PCR products were sequenced via Sanger sequencing by Macrogen Inc, South Korea. Consensus sequences were obtained by assembling contings in Geneious Prime (version 2019.1, Biomatters, Inc., San Diego, CA, USA). The sequences were compared with those deposited in GenBank ${ }^{20}$ database. A matrix with nucleotide sequences representative of the different genera and species included in the present study were subsequently created and aligned using the ClustalW tool, implemented in the MEGA software ${ }^{21}$.

\section{Phylogenetic analysis}

The sequences did not show insertions/deletions (indels); therefore, no gap treatment was performed. The phylogenetic inference was made using the NeighborJoining method with the Kimura 2 parameter models (K2P) implemented in the MEGA software ${ }^{21}$. To assess the support of the phylogenetic tree topology, a resampling corresponding to 1,000 bootstrap replicates was performed. The consensus tree was visualized and edited in the MEGA software ${ }^{21}$.

\section{RESULTS}

During our study, we collected and taxonomically identified 123 mosquitoes. The following genera were identified: Aedes $(\mathrm{n}=2)$, Anopheles $(\mathrm{n}=4)$, Johnbelikinia $(\mathrm{n}=72)$, Psorophora $(\mathrm{n}=25)$, Sabethes $(\mathrm{n}=4)$, Trichoprosopon $(\mathrm{n}=1)$, and Wyeomyia $(\mathrm{n}=15)$. Seven species were identified via a combination of classical taxonomy and molecular analysis: Aedes (Ochlerotatus) serratus (Theobald, 1901), Jonhbelkinia ulopus (Dyar \& Knab, 1906), Psorophora (Janthinosoma) ferox (Von Humboldt, 1819), Sabethes (Sabethes) cyaneus (Fabricius, 1805), Wyeomyia (Triamyia) aporonoma (Dyar \& Knab, 1906), Wyeomyia (Decamyia) pseudopecten, and Wyeomyia (Decamyia) ulocoma (Theoblad, 1903). Two additional species, Sabethes (Sabethoides) chloropterus (von Humboldt, 1819) and Wyeomyia (Dendromyia) luteoventralis (Theobald, 1901) were identified through classical and molecular taxonomy, respectively. It was not possible to identify another morphotype belonging to the genus Sabethes, because of the poor preservation of some morphological structures preventing us from using taxonomic keys and the nucleotide sequence of COI that were distantly related to any other previously deposited sequence in publicly available databases. All the species reported in the present study have been previously recorded in some areas of Colombia (Supplementary Table S1).

Seventeen sequences of the COI gene (658 bp) were obtained and deposited in GenBank database corresponding to the mosquitoes in this study (Table 1). Eight species were confirmed through the GenBank database, with similarities varying from $96.19 \%$ to $99.54 \%$. Only Ae. serratus and Ps. ferox had more than 15 sequences in open-access databases, and Jo. ulopus, Sa. cyaneus, Wy. aporonoma, 
Table 1 - Molecular identification of species via database searching and availability of COI sequences*.

\begin{tabular}{|c|c|c|c|}
\hline Species & Obtained Sequences & $\begin{array}{c}\text { Related Sequence from } \\
\text { GenBank }\end{array}$ & Similarity (\%) GenBank \\
\hline Ae. serratus & MT418595 & MF172270 & 99.06 \\
\hline \multirow[t]{3}{*}{ Ps.ferox } & MT418592 & MG242536 & 99.06 \\
\hline & MT418593 & MN997516 & 99.54 \\
\hline & MT418594 & MN997519 & 99.39 \\
\hline \multirow[t]{5}{*}{ Jo. ulopus } & MT418581 & MF172329 & 96.30 \\
\hline & MT418582 & MF172329 & 96.35 \\
\hline & MT418583 & MF172329 & 96.35 \\
\hline & MT418584 & MF172329 & 96.35 \\
\hline & MT418585 & MF172329 & 96.19 \\
\hline Sa.cyaneus & MT418579 & GU908121 & 97.59 \\
\hline Sabethes sp. & MT418588 & NC_044660 & 88.96 \\
\hline Wy. aporonoma & MT418589 & MF172423 & 98.60 \\
\hline \multirow[t]{2}{*}{ Wy.pseudopecten } & MT418590 & MF172493 & 99.53 \\
\hline & MT418591 & MF172493 & 98.63 \\
\hline \multirow[t]{2}{*}{ Wy. ulocoma } & MT418586 & KF671038 & 96.28 \\
\hline & MT418587 & KF671038 & 96.35 \\
\hline Wy. luteoventralis & MT418580 & MF172452 & 97.35 \\
\hline
\end{tabular}

*Data accessed in October 2019.

Wy. pseudopecten, and Wy. ulocoma species had less than 15 accessible sequences. The Sabethes species was not confirmed through the database, and its identification was ambiguous; using GenBank, an identity value $<88.43 \%$ was observed when compared to Sa. (Peytonulus) hadrognatus (Harbach, 1995) and Wy. (Dendromyia) ypsipola (Dyar, 1922).

In a first phylogenetic reconstruction using a partial COI sequence ( $353 \mathrm{bp}$ ) for all the major taxa of interest, the tribes Aedini and Sabethini were identified as monophyletic clusters (data not shown). Taxonomic identification at the species level was confirmed for Ae. serratus, Ps. ferox, Jo. ulopus, Sa. cyaneus, Wy. aporonoma, Wy. pseudopecten, Wy. ulocoma, and Wy. luteoventralis. However, there was not clear clusters for the genera Johnbelkinia, Wyeomyia, Sabethes, Trichoprosopon and Limatus. Also, the species Ae. aegypti was clustered with species of the genus Culex such as: Cx. corniger (KP281757), Cx. erythrotorax (HM593011), Cx. nigripalpus (KP281764), and others.

Due to these inconsistencies, a more detailed phylogenetic reconstruction was performed independently for the Aedini (Figure 2) and Sabethini (Figure 3) tribes using more informative datasets of 530 and $447 \mathrm{bp}$, respectively. Within the Sabethini tribe, monophyletic clusters representing the different genera were not identified. The mosquito sample CIST0314 was identified through classical morphology as a member of the genus Sabethes. In the phylogenetic tree, the corresponding sequence with accession number MT418588 was more closely related to the genera Johnbelikinia and Wyeomyia.

The sequence (KM593040) of Wyeomyia (Dendromyia) luteoventralis (Theobald, 1901) previously reported in Colombia, fell into the Wy. pseudopecten cluster in the current study (Figure 3). Also, the species Ae. euiris (MK592988) fell into the genus Haemagogus in the present analysis (Figure 2). The intra-species genetic variation was 0,007 for Wy. aporonoma and higher 0,0211 to 0,0511 for the other species in this study (Table 2). Sabethes sp. was not related to species previously reported in databases.

\section{DISCUSSION}

The present study allowed us to address mosquito diversity in the SNSM ecosystem and to describe the presence of potential arboviral vectors in this area of the country. This study is the first to report the identification of Ae. serratus, Jo. ulopus, Wy. aporonoma, Wy. pseudopecten, and Wy. ulocoma in the SNSM rainforest at the molecular and morphologic levels. The accurate identification of vector species is an essential factor in the study of arboviral diseases, allowing the local health authorities to target resources for vector control strategies ${ }^{22}$.

In this study, we achieved the identification of seven species that are mainly associated with rural environments. 


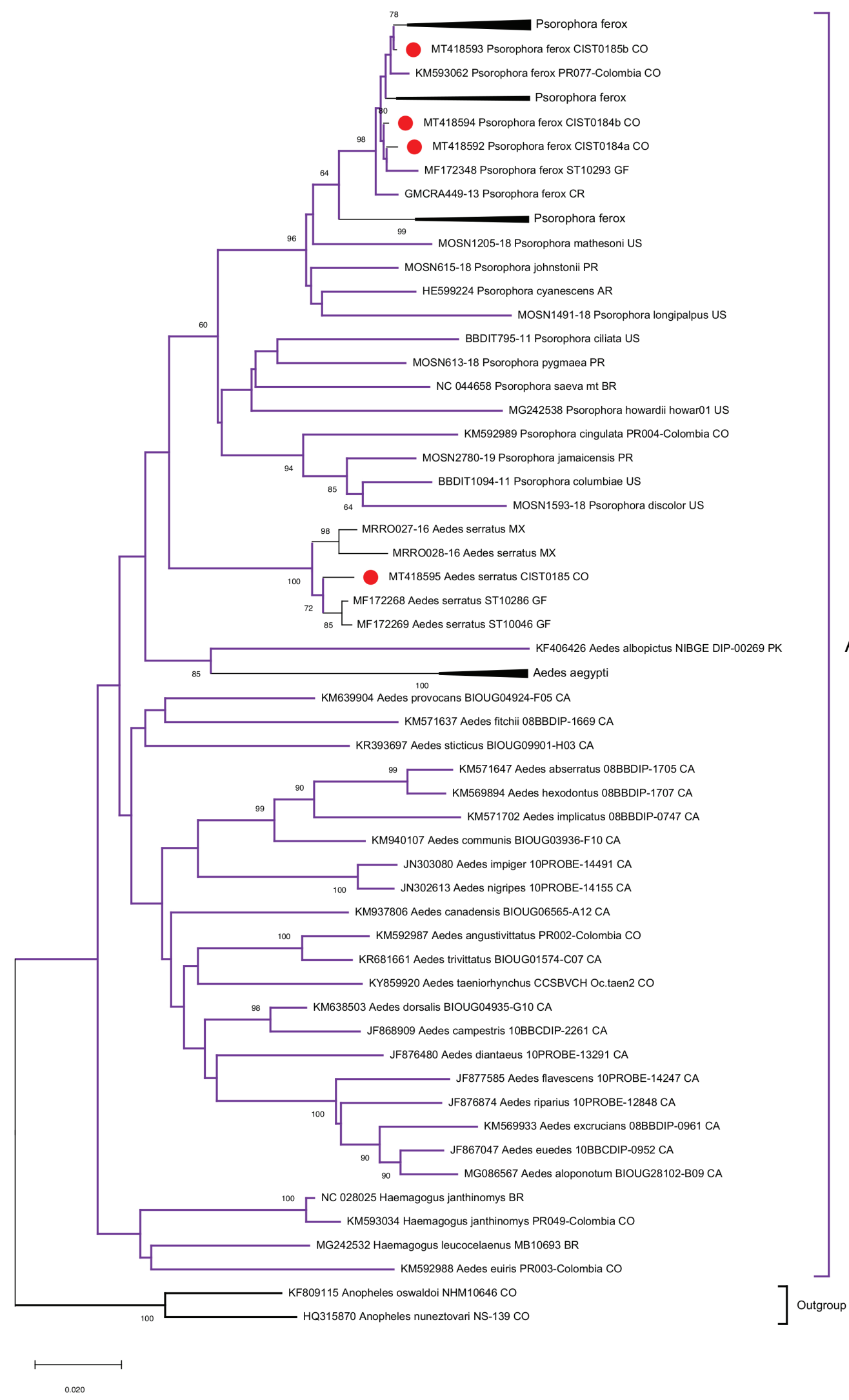

Figure 2 - Phylogenetic reconstruction of the Aedini tribe using the COI gene (530 bp). The Neighbor-Joining method was used, and the best nucleotide substitution model was K2P, with 1,000 bootstrap replicates. Sequences in the present study are highlighted in red circles. Bootstrap supports above 60 are shown. An external cluster included An. (Nyssorhynchus) oswaldoi (Peryassú, 1922) and An. (Nyssorhynchus) nuneztovari (Gabaldón, 1940). 


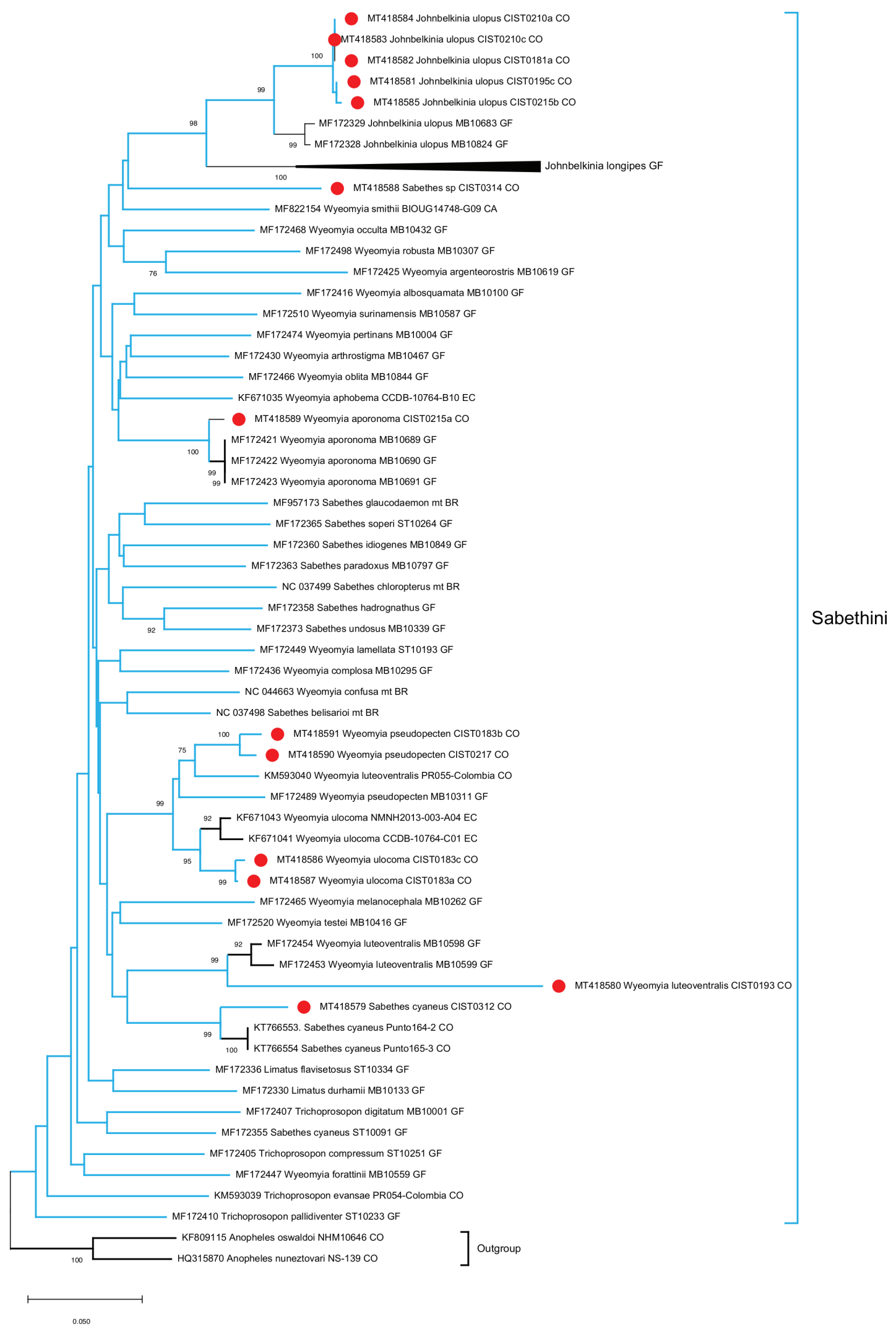

Figure 3 - Phylogenetic reconstruction of the Sabethini tribe using the COI gene (447 bp). The Neighbor-Joining method was used, and the best nucleotide substitution model was K2P, with 1,000 bootstrap replicates. Sequences in the present study are highlighted in red circles. Bootstrap supports above 60 are shown. An external cluster included An. (Nyssorhynchus) oswaldoi (Peryassú, 1922) and An. (Nyssorhynchus) nuneztovari (Gabaldón, 1940). 
Table 2 - Average intra-species genetic distance for eight mosquito species identified in the present study*.

\begin{tabular}{lcc}
\hline Species & $\begin{array}{c}\text { Average intra- } \\
\text { species distance } \\
\left(\text { distance-p) }^{\star *}\right.\end{array}$ & $\begin{array}{c}\text { Average intra- } \\
\text { species distance } \\
(\mathrm{K} 2 \mathrm{P})^{\star \star *}\end{array}$ \\
\hline Ae. serratus & 0.0443 & 0.0489 \\
Ps. ferox & 0.0211 & 0.0219 \\
Jo. ulopus & 0.0216 & 0.0227 \\
Sa. cyaneus & 0.0432 & 0.0458 \\
Wy. aporonoma & 0.0070 & 0.0071 \\
Wy. pseudopecten & 0.0374 & 0.0398 \\
Wy. ulocoma & 0.0256 & 0.0269 \\
Wy. luteoventralis & 0.0511 & 0.0547 \\
\hline
\end{tabular}

${ }^{*}$ The $p$ distances were calculated for each species included in this study by using representative sequences from GenBank accessed in October 2019; ${ }^{\star *}$ Number of nucleotide changes between pairs of sequences per 100 nucleotides; ${ }^{\star * *}$ Number of nucleotide changes (1 or more) between pairs of sequences per 100 nucleotides adjusted to the K2P evolutionary model, taking more frequent transitions than transversions.

Some of these species are under or not represented at all in the GenBank database according to an accurate identification (e.g., CIST0314 Sabethes sp.). In the case of other species such as Wy. aporonoma, Wy. luteoventralis, Wy. pseudopecten, Wy. ulocoma, Jo. ulopus, Sa. chloropterus, and Sa. cyaneus that are mainly associated with sylvatic ecosystems, the identification was also challenging because of the lack of information about their biology, ecology and genetics.

Sequences that led to the identification of Ae. serratus and Ochlerotatus serratus as the same species are found in the GenBank database due to taxonomic reclassification that has been proposed for the Aedini tribe; however, a recent analysis supported the use of the traditional classification ${ }^{23}$. In addition, there are difficulties in classifying the genus Psorophora due to similar male genitalia morphology among species ${ }^{24}$.

In this study, some specimens were initially classified as Trichoprosopon sp., using taxonomic keys that did not include the new genus Johnbelkinia. After the reclassification via the morphological characters of the absence of sows in the calypter and the iridescent yellow-green colors on the mosquito scutal ${ }^{18}$, in which Jo. ulopus and Jo. longipes adult, morphology are well-described, we identified the morphotype as Jo. ulopus and the species designation was corroborated by DNA barcoding.

The Sabethini tribe has been classified as a monophyletic group using morphological characters, but when trying to show the phylogenetic relationships at the genus level, there were difficulties to find natural groups for several genera, including Sabethes and Wyeomyia ${ }^{25,26}$. In addition, Wy. compta (Senevet \& Abonnenc, 1939) and Wy. argenteorostris (Bonne-Wepster \& Bonne, 1920) are the same species that were initially named as two different species due to classification errors by the classical taxonomy ${ }^{27}$. It is mandatory to specify the taxonomic key used for species identification in order to consider the taxonomic classification updates.

Studies with Ae. aegypti showed a close phylogenetic relationship with $\mathrm{Hg}$. equinus (Theobald. 1903) ${ }^{28}$ and members of the genus Psorophora ${ }^{29}$. Ae. serratus from our study, collected in the sylvatic area showed a close relationship with sequences from the French Guyana and a more distant relationship with sequences from Mexico. Currently, the circulation of this species is mainly limited to sylvatic settings, although larvae and adults have been found at intra- and extra-domiciliary levels in low abundances, not significant to define mosquito circulation in urban areas ${ }^{17}$.

The wide circulation of Ps. ferox has allowed the establishment of populations that begin to have betweenpopulation morphological differences, with intra-species variability in the egg and exochorion ${ }^{30}$. Genetic variability has also been observed in South, Central, and North American populations of this mosquito species identified in our study, suggesting that more in-depth morphological studies in these geographical regions should be conducted to identify changes in the life cycle stages.

Wy. aporonoma could have a wide distribution and circulation in the mountain ranges and rainforests in South American countries, although there are only reports in the French Guiana and Colombia at this time ${ }^{31}$.

The species that have been previously reported as Wy. luteoventralis (KM593040) in the department of Antioquia, Colombia ${ }^{11}$ resulted in similarities of 95.74\% with $W y$. pseudopecten when analyzed through BLAST-GenBank. In our study, this sequence has also shown a closer phylogenetic relationship with the $W y$. pseudopecten cluster.

All the species initially characterized in this study may constitute potential arboviruses vectors with public health implications. Ae. serratus, Sa. chloropterus, and Ps. ferox could have acted as bridge vectors that led to the establishment of the YFV sylvatic cycle ${ }^{13}$, responsible for the enzootic and epizootic transmission in this region of the country and a potential risk for human cases, mainly in rural areas. In the future, these mosquitoes may also serve as vectors for epidemic arboviruses to spillback in the Americas, such as DENV, CHIKV, and ZIKV ${ }^{32}$.

The biogeographic features of the SNSM rainforest make it a rich area of speciation due to the isolation of populations as a consequence of the mountain ranges rising. In addition, it is close to the Serrania del Perija and other natural parks 
in the same region that have been classified as speciation zones $^{33}$ due to their high diversity of fauna ${ }^{34}$ and flora ${ }^{35}$. This study allowed us to corroborate the complementarity that exists between classical and molecular taxonomy. Further molecular taxonomy studies are required due to limitations of classical taxonomic keys. The keys used may be outdated regarding morphological characteristics of the species described; molecular identification tools have improved over time allowing the expansive characterization of sylvatic mosquitoes through genes ${ }^{36}$ or complete mitochondrial genomes to identify species and reconstruct phylogenies ${ }^{37}$. However, the availability of sequences for sylvatic mosquito species is limited and more studies are needed to provide a greater support to the species identification.

Species such as Ps. ferox have a long dispersal ability from fragment forest to open areas, enabling its wide distribution range and the potential dispersion of arboviruses to susceptible hosts as human population and domestic animals. Additionally, the changes in populations or communities of mosquitoes in rural environments, due to the habitat fragmentation and anthropogenic disturbances inside conserved ecosystems (rainforest) could accelerate outbreaks and potentially epidemic situation ${ }^{38,39}$. In this sense, the ecological settings in rural areas of the SNSM meet the requirements for the emergence of viruses and other pathogens.

\section{CONCLUSION}

In conclusion, a possible endemicity in the studied region reinforces the importance of developing regional DNA barcoding libraries for molecular species identification. The high diversity of mosquito species identified in the SNSM and the limitations for taxonomic assignment reinforces the need for a consensus in the classical taxonomy and the availability of curated sequences in the open-access databases for the proper use of DNA barcoding.

\section{ACKNOWLEDGMENTS}

We thank entomologist Victor Alberto Olano from the Health and Environment group of the Universidad El Bosque for his support with species identification via classical taxonomy. We also thank the technicians Adalberto Duica and Juan Domínguez (Department of Health, Santa Maria District) for field work assistance.

\section{AUTHORS' CONTRIBUTIONS}

GJPH, JAUC and KLD conceived and designed the study. GJPH and ASMG carried out the taxonomic identification. JAUC, KLD and ASMG performed the DNA extraction and other experiments. JAUC, KLD and ASMG analyzed the molecular data. ASMG, JAUC, GJPH and KLD wrote the manuscript. All authors edited, read, and approved the final manuscript.

\section{FUNDING}

This study was financed and supported by the Ministry of Science, Technology, and Innovation in Health (Minciencias), Colombia, project 210477757671 (Virologic Expedition in Representative Ecosystems of Colombia: Tropical Rainforest of the Sierra Nevada de Santa Marta) to JAUC.

\section{REFERENCES}

1. Harbach RE. The Culicidae (Diptera): a review of taxonomy, classification and phylogeny. Zootaxa. 2007;16681:591-638.

2. World Health Organization. Vector-borne diseases: key facts. [cited 2021 Jan 21]. Available from: https://www.who.int/en/ news-room/fact-sheets/detail/vector-borne-diseases

3. Vasilakis N, Cardosa J, Hanley KA, Holmes EC, Weaver SC. Fever from the forest: prospects for the continued emergence of sylvatic dengue virus and its impact on public health. Nat Rev Microbiol. 2011;9:532-41.

4. Cova GP, Tallaferro DE, Sutil OE. General principles of entomology. Montevideo: Fundación Venezolana para la Salud y la Educación; 1974.

5. International Commission on Zoological Nomenclature. International code of zoological nomenclature. $4^{\text {th }}$ ed. London: International Trust for Zoological Nomenclature; 1999. [cited 2021 Jan 21] Available from: https://www.iczn.org/the-code/ the-international-code-of-zoological-nomenclature/the-codeonline/

6. Kress WJ, Garcia-Robledo C, Uriarte M, Erickson DL. DNA barcodes for ecology, evolution, and conservation. Trends Ecol Evol. 2015;30:25-35.

7. Shah MA, Khan AA, Khan HZ. DNA barcoding-applications in insect ecology. Indian J Ecol. 2015;42:287-94.

8. Arnot DE, Roper C, Bayoumi RA. Digital codes from hypervariable tandemly repeated DNA sequences in the Plasmodium falciparum circumsporozoite gene can genetically barcode isolates. Mol Biochem Parasitol. 1993;61:15-24.

9. Hebert PD, Ratnasingham S, deWaard JR. Barcoding animal life: cytochrome c oxidase subunit 1 divergences among closely related species. Proc Biol Sci. 2003;270 Suppl 1:S96-9.

10. Naranjo-Diaz N, Rosero DA, Rua-Uribe G, Luckhart S, Correa MM. Abundance, behavior and entomological inoculation rates of anthropophilic anophelines from a primary Colombian malaria endemic area. Parasit Vectors. 2013;6:61. 
11. Rozo-Lopez P, Mengual X. Mosquito species (Diptera, Culicidae) in three ecosystems from the Colombian Andes: identification through DNA barcoding and adult morphology. Zookeys. 2015;513:39-64.

12. Sánchez J, Galeano, Y, Rosero DA, Naranjo NJ, Correa MM. Confirmación molecular de especie en especímenes Anopheles recolectados en el corregimiento de Juan José, Puerto Libertador, Córdoba, Colombia. Hechos Microbiol. 2011;2:1928.

13. Vidales H, Buitrago B, Sanín LH, Morales A, Groot H. Estudio de un brote epidémico de fiebre amarilla selvática en el pie de monte de La Sierra Nevada de Santa Marta, 1979. Biomédica. 1981;1:171-86

14. Balaguera L, Cantillo J, Camargo LF, Gómez A, Jiménez M, Laverde GN, et al. Plan de manejo Parque Nacional Natural Sierra Nevada de Santa Marta. Santa Marta: Unidad Administrativa Especial del Sistema de Parques Nacionales Naturales; 2015. [cited 2021 Jan 21]. Available from: https://www.parquesnacionales.gov.co/portal/wp-content/ uploads/2013/12/parqueSierraNevadadeSantaMarta.pdf

15. Colombia. Banco de la República. Sierra Nevada de Santa Marta: economía de sus recursos naturales. [cited 2021 Jan 21]. Available from: https://www.banrep.gov.co/es/sierra-nevadasanta-marta-economia-sus-recursos-naturales

16. Gonzáles Obando R, Carrejo Gironza NS. Introducción al estudio taxonómico de Anopheles de Colombia: claves y notas de distribución. $2^{\text {a }}$ ed. Cali: Universidad Del Valle; 2009.

17. Forattini OP. Culicidologia médica: identificaçäo, biologia e epidemiologia. São Paulo: EDUSP; 2002.

18. Zavortink TJ. Mosquito studies (Diptera, Culicidae) XXXV. The new Sabethine genus Johnbelkinia and a preliminary reclassification of the composite genus Trichoprosopon. Contrib Am Entomol Inst. 1979;17:1-61.

19. Folmer O, Black M, Hoeh W, Lutz R, Vrijenhoek R. DNA primers for amplification of mitochondrial cytochrome $\mathrm{c}$ oxidase subunit I from diverse metazoan invertebrates. Mol Mar Biol Biotechnol. 1994;3:294-9.

20. National Center for Biotechnology Information. BLAST ${ }^{\circledR}$ [cited 2021 Jan 21]. Available from: https://blast.ncbi. nlm.nih.gov/Blast.cgi?PROGRAM=blastn\&PAGE_ TYPE=BlastSearch\&LINK_LOC=blasthome

21. Kumar S, Stecher G, Li M, Knyaz C, Tamura K. MEGA X: Molecular Evolutionary Genetics Analysis across Computing Platforms. Mol Biol Evol. 2018;35:1547-9.

22. Ruiz-Lopez F, Wilkerson RC, Conn JE, McKeon SN, Levin D, Quiñonez ML, et al. DNA barcoding reveals both known and novel taxa in the Albitarsis Group (Anopheles: Nyssorhynchus) of Neotropical malaria vectors. Parasit Vectors. 2012;5:44

23. Wilkerson RC, Linton YM, Fonseca DM, Schultz TR, Price DC, Strickman DA. Making mosquito taxonomy useful: a stable classification of tribe Aedini that balances utility with current knowledge of evolutionary relationships. PLoS One. 2015;10:e133602.

24. Liria J, Navarro JC. Phylogenetic relationships in the genus Psorophora Robineau-Desvoidy based on morphological characters. Entomol Appl Sci Lett. 2014;1:22-50.

25. Judd DD. Review of the systematics and phylogenetic relationships of the Sabethini (Diptera: Culicidae). Syst Entomol. 1996;21:129-50.

26. Motta MA, Lourenço-de-Oliveira R, Sallum MA. Phylogeny of genus Wyeomyia (Diptera: Culicidae) inferred from morphological and allozyme data. Can Entomol. 2007;139:591627.

27. Nascimento-Pereira AC, Talaga S, Guimarães AE, Lourenço-deOliveira R, Motta MA. Taxonomic history of species without subgeneric placement in the genus Wyeomyia Theobald (Diptera: Culicidae) and recognition of Wy. compta Senevet amp; Abonnenc as a junior synonym of Wy. argenteorostris (Bonne-Wepster amp; Bonne). Zootaxa. 2019;4656:359-6.

28. Chan-Chable RJ, Martinez-Arce A, Mis-Avila PC, OrtegaMorales AI. DNA barcodes and evidence of cryptic diversity of anthropophagous mosquitoes in Quintana Roo, Mexico. Ecol Evol. 2019;9:4692-705.

29. Soghigian J, Andreadis TG, Livdahl TP. From ground pools to treeholes: convergent evolution of habitat and phenotype in Aedes mosquitoes. BMC Evol Biol. 2017;17:262.

30. Mello CF, Santos-Mallet JR, Tatila-Ferreira A, Alencar J. Comparing the egg ultrastructure of three Psorophora ferox (Diptera: Culicidae) populations. Braz J Biol. 2018;78:505-8.

31. Talaga S, Leroy C, Guidez A, Dusfour I, Girod R, Dejean A, et al. DNA reference libraries of French Guianese mosquitoes for barcoding and metabarcoding. PLoS One. 2017;12:e176993.

32. Weaver SC, Chen R, Diallo M. Chikungunya virus: role of vectors in emergence from enzootic cycles. Annu Rev Entomol. 2020;65:313-32.

33. Talaga S, Murienne J, Dejean A, Leroy C. Online database for mosquito (Diptera, Culicidae) occurrence records in French Guiana. Zookeys. 2015;532:107-15.

34. Fergnani PN, Ruggiero A. Ecological diversity in South American mammals: their geographical distribution shows variable associations with phylogenetic diversity and does not follow the latitudinal richness gradient. PLoS One. 2015;10:e128264.

35. Navarro JC, Liria J, Piñango H, Barrera R. Biogeographic area relationships in Venezuela: a Parsimony analysis of Culicidae: Phytotelmata distribution in National Parks. Zootaxa. 2007;1547:1-19.

36. Aragão AO, Nunes Neto JP, Cruz AC, Casseb SM, Cardoso JF, Silva SP, et al. Description and phylogeny of the mitochondrial genome of Sabethes chloropterus, Sabethes glaucodaemon and Sabethes belisarioi (Diptera: Culicidae). Genomics. 2019;111:607-11.

37. Lorenz C, Alves JM, Foster PG, Sallum MA, Suesdek L. First 
record of translocation in Culicidae (Diptera) mitogenomes: evidence from the tribe Sabethini. BMC Genomics. 2019;20:721.

38. Hoyos-López R, Suaza-Vasco J, Rúa-Uribe G, Uribe S, Gallego-Gómez JC. Molecular detection of flaviviruses and alphaviruses in mosquitoes (Diptera: Culicidae) from coastal ecosystems in the Colombian Caribbean. Mem Inst Oswaldo Cruz. 2016;111:625-34.

39. Hoyos-López R, Uribe S, Rúa-Uribe G, Gallego-Gómez JC. Molecular identification of Saint Louis Encephalitis Virus genotype IV in Colombia. Mem Inst Oswaldo Cruz. 2015;110:719-25.

\section{SUPPLEMENTARY MATERIAL}

Table S1 - Geographical records of mosquitoes in Colombia and associated arboviruses ${ }^{1}$

\begin{tabular}{|c|c|c|c|c|}
\hline Species & Department & References $^{2}$ & Associated arbovirus & References $^{2}$ \\
\hline Wy. aporonoma & Valle & $\begin{array}{c}\text { Heinemann and Belkin }{ }^{14} \\
\text { Barreto et al. }{ }^{2}\end{array}$ & -- & -- \\
\hline Wy. luteoventralis & Antioquia & Rozo-López and Mengual28 & -- & -- \\
\hline Jo. ulopus & $\begin{array}{c}\text { Boyacá } \\
\text { Meta } \\
\text { Nariño } \\
\text { Norte de Santander } \\
\text { Valle del Cauca } \\
\text { Antioquia } \\
\text { Caldas }\end{array}$ & Suaza-Vasco et al. ${ }^{30}$ & -- & -- \\
\hline Wy.pseudopecten & Valle del Cauca & Suaza-Vasco et al. ${ }^{30}$ & -- & -- \\
\hline Wy. ulocoma & Valle del Cauca & Suaza-Vasco et al. ${ }^{30}$ & -- & -- \\
\hline & Meta & Bates $^{3}$ & & \\
\hline Sa guanouc & Valle del Cauca & Suaza-Vasco et al..$^{30}$ & & \\
\hline sa.cyameus & Caquetá & Molina et al. ${ }^{20}$ & & \\
\hline & Córdoba & Hoyos-López et al. ${ }^{16}$ & & \\
\hline Sa. chloropterus & $\begin{array}{c}\text { Meta } \\
\text { Valle del Cauca } \\
\text { Caquetá } \\
\text { Córdoba }\end{array}$ & $\begin{array}{c}\text { Bates }^{3} \\
\text { Suaza-Vasco et al. }{ }^{30} \\
\text { Molina et al. }{ }^{20} \\
\text { Hoyos-López et al. }{ }^{16}\end{array}$ & $\begin{array}{l}\text { Primary vector: Yellow } \\
\text { fever virus (YFV) }\end{array}$ & $\begin{array}{l}\text { Galindo }{ }^{10} \\
\text { Galindo et al. }{ }^{11} \\
\text { Zsemlye et al. } .^{31}\end{array}$ \\
\hline \multirow{6}{*}{ Ae. serratus } & Antioquia & $\begin{array}{c}\text { López }^{19} \\
\text { Groot }^{12} \\
\text { Barreto et al. }{ }^{2} \\
\text { Parra-Henao and Suarez }\end{array}$ & \multirow[t]{2}{*}{$\begin{array}{c}\text { Secondary vector: Yellow } \\
\text { fever virus (YFV) }\end{array}$} & \multirow[t]{2}{*}{$\begin{array}{l}\text { Cardoso et al. } \\
\text { Sick et al. }{ }^{29} \\
\text { Pinheiro et al. } .^{27}\end{array}$} \\
\hline & Meta & Antunes $^{1}$ & & \\
\hline & Caquetá & Molina et al. ${ }^{20}$ & Mayaro virus (MAYV) & Muñoz and Navarro 23 \\
\hline & Córdoba & $\begin{array}{l}\text { Heinemann and Belkin }{ }^{14} \\
\text { Morales and Vidales }\end{array}$ & \multirow{3}{*}{$\begin{array}{c}\text { Venezuelan equine } \\
\text { encephalitis virus } \\
\text { (EEV) }\end{array}$} & \multirow{3}{*}{ Molina et al. ${ }^{20}$} \\
\hline & Valle del Cauca & Lee and Barreto ${ }^{18}$ & & \\
\hline & Santander & $\begin{array}{l}\text { Ferro et al. }{ }^{8} \\
\text { Groot et al. }{ }^{13}\end{array}$ & & \\
\hline \multirow{5}{*}{ Ps.ferox } & \multirow[b]{2}{*}{ Antioquia } & \multirow{2}{*}{$\begin{array}{l}\text { Rozo-López and Mengual }{ }^{28} \\
\text { Hoyos-López } \\
\text { Parra-Henao and Suarez }{ }^{26}\end{array}$} & West Nile virus (WNV) & Christofferson et al. ${ }^{6}$ \\
\hline & & & $\begin{array}{c}\text { Eastern equine } \\
\text { encephalitis (EEEV) }\end{array}$ & $\begin{array}{l}\text { Navia-Gine et al. }{ }^{24} \\
\text { Oliver et al. }{ }^{25}\end{array}$ \\
\hline & Valle del Cauca & Figueroa $^{9}$ & $\begin{array}{c}\text { St Louis encephalitis } \\
\text { virus (SLEV) }\end{array}$ & Beranek et al. ${ }^{4}$ \\
\hline & - & - & Madariaga virus (MADV) & Lednicky et al. ${ }^{17}$ \\
\hline & $\begin{array}{c}\text { Caquetá } \\
\text { Guajira } \\
\text { Magdalena }\end{array}$ & $\begin{array}{c}\text { Molina et al. }{ }^{20} \\
\text { Morales et al. }{ }^{21} \\
\text { Dickerman et al. }{ }^{7}\end{array}$ & $\begin{array}{c}\text { Venezuelan equine } \\
\text { encephalitis virus } \\
\text { (EEV) }\end{array}$ & Molina et al. ${ }^{20}$ \\
\hline
\end{tabular}

${ }^{1}$ data accessed in October 2019; ${ }^{2}$ all references included in the table are listed below. 


\section{REFERENCES OF TABLE S1}

1. Antunes PC. Informe sobre una investigacion entomologica realizada en Colombia. Rev Fac Med. 1937;6:65-87.

2. Barreto M, Burbano ME, Suárez M, Barreto P. Psorophora ciliata y otros mosquitos (Diptera: Culicidae) en Yolombó, Antioquia, Colombia. Colombia Med. 1996;27:62-5.

3. Bates M. Observations on Climate and Seasonal Distribution of Mosquitoes in Eastern Colombia. J Anim Ecol. 1945;14:17-25.

4. Beranek MD, Gallardo R, Almirón WR, Contigiani MS. First detection of Mansonia titillans (Diptera: Culicidae) infected with St. Louis encephalitis virus (Flaviviridae: Flavivirus) and Bunyamwera serogroup (Peribunyaviridae: Orthobunyavirus) in Argentina. J Vector Ecol. 2018;43:340-3.

5. Cardoso JC, Almeida MA, Santos E, Fonseca DF, Sallum MA, Noll CA, et al. Yellow fever virus in Haemagogus leucocelaenus and Aedes serratus mosquitoes, Southern Brazil. Emerg Infect Dis. 2010;16:1918-24.

6. Christofferson RC, Roy AF, Mores CN. Factors associated with mosquito pool positivity and the characterization of the West Nile viruses found within Louisiana during 2007. Virol J. 2010;7:139.

7. Dickerman RK, Cupp EW, Groot H, Azarcón AM, Cura E, Dickerman AK, et al. Actividad del virus de la encefalitis equina venezolana en el norte de Colombia, abril y mayo de 1983. Bol Oficina Sanit Panam. 1987;103:1-7.

8. Ferro MC, Olano VA, Ahumada M, Weaver S. Mosquitos (Diptera: Culicidae) en el caserío de Chingalé, Santander, donde se registró un caso humano de encefalitis equina venezolana. Biomédica. 2008;28:234-44.

9. Figueroa PA. Catalogo de los artropodos de las clases Arachnida e Insecta encontrados en el hombre, los animales y las plantas de la republica de Colombia-III. Acta Agron. 1953;3:1-7.

10. Galindo P. Bionomics of Sabethes chloropterus Humboldt, a vector of sylvan yellow fever in Middle America. Am J Trop Med Hyg. 1958;7:429-40.

11. Rodaniche E, Galindo P, Trapido H. Experimental transmission of yellow fever by central american species of Haemagogus and Sabethes Chloropterus. Am J Trop Med Hyg. 1956;5:1022-31.

12. Groot H. Estudios sobre virus transmitidos por artrópodos en Colombia. Rev Acad Colomb Cienc Ex Fis Nat. 1964;12:191217.

13. Groot H, Morales A, Vidales H. Virus isolations from forest mosquitoes in san Vicente de chucuri, Colombia. Am J Trop Med Hyg. 1961;10:397-402.

14. Heinemann SJ, Belkin JN. Collection records of the Project "Mosquitoes of Middle America": 7. Costa Rica (CR). Mosq Syst. 1977;9:237-87.

15. Hoyos-López R. Molecular Typing with COI-DNA Barcode of mosquitoes with medical importance from rural area of La Pintada, Antioquia, Colombia. BioRxiv. In Press 2018.
16. Hoyos-López R, Soto SU, Rúa-Uribe G, Gallego-Gómez JC. Molecular identification of saint louis encephalitis virus genotype IV in Colombia. Mem Inst Oswaldo Cruz. 2015;110:719-25.

17. Lednicky JA, White SK, Mavian CN, Badry MA, Telisma T, Salemi M, et al. Emergence of Madariaga virus as a cause of acute febrile illness in children, Haiti, 2015-2016. PLoS Negl Trop Dis. 2019;13:e006972.

18. Lee VH, Barreto P. Artrópodos hematófagos del río Raposo, Valle, Colombia: I - Aspectos ecológicos. Caldasia. 1969;10:385-405.

19. López Y. Informe de un muestreo entomológico en la cabecera municipal de Vigía del Fuerte. Bol Vectores. 1990;1:3-5.

20. Molina JA. Hildebrand P, Olano VA, Hoyos PM, Barreto M, Guhl F. Fauna de insectos hematófagos del sur del Parque Natural Nacional Chiribiquete, Caquetá, Colombia. Biomédica. 2000;20:314-26.

21. Morales A, Ferro C, Rodríguez CI, Cura E. Encuesta sobre artropodos de interés médico en La Guajira, Colombia, Suramérica. Biomédica. 1987;7:87-94.

22. Morales A, Vidales H. Distribución de mosquitos selváticos en San Vicente de Chucurí, Colombia. Lozania. 1962;13:1-16.

23. Muñoz M, Navarro JC. Virus Mayaro: un arbovirus reemergente en Venezuela y Latinoamérica. Biomédica. 2012;32:286-302.

24. Navia-Gine WG, Loaiza JR, Miller MJ. Mosquito-host interactions during and after an outbreak of equine viral encephalitis in eastern Panama. PLoS One. 2013;12:e81788.

25. Oliver J, Lukacik G, Kokas J, Campbell SR, Kramer LD, Sherwood JA, et al. Twenty years of surveillance for Eastern equine encephalitis virus in mosquitoes in New York State from 1993 to 2012. Parasit Vectors. 2018;11:362.

26. Parra-Henao G, Suárez L. Mosquitos (Díptera: Culicidae) vectores potenciales de arbovirus en la región de Urabá, noroccidente de Colombia. Biomédica. 2012;32:252-62.

27. Pinheiro GG, Rocha MN, Oliveira MA, Moreira LA, Andrade Filho JD. Detection of yellow fever virus in sylvatic mosquitoes during disease outbreaks of 2017-2018 in minas gerais state, Brazil. Insects. 2019;10:136.

28. Rozo-Lopez P, Mengual X. Mosquito species (Diptera, Culicidae) in three ecosystems from the Colombian Andes: identification through DNA barcoding and adult morphology. Zookeys. 2015;513:39-64.

29. Sick F, Beer M, Kampen H, Wernike K. Culicoides biting midges underestimated vectors for arboviruses of public health and veterinary importance. Viruses. 2019;11:376.

30. Suaza-Vasco J, López-Rubio A, Galeano J, Uribe S, Vélez I, Porter C. The sabethines of Northern Andean coffee-growing regions of Colombia. J Am Mosq Control Assoc. 2015;31:125-34.

31. Zsemlye JL, Hancock RG, Foster WA. Analysis of a complex vertical copulatory-courtship display in the yellow fever vector Sabethes chloropterus. Med Vet Entomol. 2005;19:276-85. 